University of Nebraska - Lincoln

DigitalCommons@University of Nebraska - Lincoln

2012

\title{
A riverscape perspective of Pacific salmonids and aquatic habitats prior to large-scale dam removal in the Elwha River, Washington, USA
}

\author{
S. J. Brenkman \\ National Park Service, sam_brenkman@nps.gov \\ Jeff J. Duda \\ U.S. Geological Survey, jduda@usgs.gov \\ Christian E. Torgersen \\ U.S. Geological Survey, ctorgersen@usgs.gov \\ Ethan Welty \\ U.S. Geological Survey, ethan.welty@colorado.edu \\ G.R. Pess \\ NOAA Northwest Fisheries Science Center \\ See next page for additional authors
}

Follow this and additional works at: https://digitalcommons.unl.edu/natlpark

Brenkman, S. J.; Duda, Jeff J.; Torgersen, Christian E.; Welty, Ethan; Pess, G.R.; Peters, R.; and Mchenry, M.L., "A riverscape perspective of Pacific salmonids and aquatic habitats prior to large-scale dam removal in the Elwha River, Washington, USA" (2012). U.S. National Park Service Publications and Papers. 45. https://digitalcommons.unl.edu/natlpark/45

This Article is brought to you for free and open access by the National Park Service at DigitalCommons@University of Nebraska - Lincoln. It has been accepted for inclusion in U.S. National Park Service Publications and Papers by an authorized administrator of DigitalCommons@University of Nebraska - Lincoln. 


\section{Authors}

S. J. Brenkman, Jeff J. Duda, Christian E. Torgersen, Ethan Welty, G.R. Pess, R. Peters, and M.L. Mchenry 


\title{
A riverscape perspective of Pacific salmonids and aquatic habitats prior to large-scale dam removal in the Elwha River, Washington, USA
}

\author{
S. J. BRENKMAN \\ National Park Service, Olympic National Park, Port Angeles, WA, USA
}

J. J. DUDA

U.S. Geological Survey, Western Fisheries Research Center, Seattle, WA, USA

\author{
C. E. TORGERSEN \& E. WELTY ${ }^{1}$ \\ U.S. Geological Survey, Forest and Rangeland Ecosystem Science Center, University of \\ Washington, College of Forest Resources, Seattle, WA, USA
}

G. R. PESS

NOAA Northwest Fisheries Science Center, Seattle, WA, USA

\author{
R. PETERS \\ U.S. Fish and Wildife Service, Lacey, WA, USA
}

\author{
M. L. MCHENRY \\ Lower Elwha Klallam Tribe, Port Angeles, WA, USA
}

\begin{abstract}
Dam removal has been increasingly proposed as a river restoration technique. In 2011, two large hydroelectric dams will be removed from Washington State's Elwha River. Ten anadromous fish populations are expected to recolonise historical habitats after dam removal. A key to understanding watershed recolonisation is the collection of spatially continuous information on fish and aquatic habitats. A riverscape approach with an emphasis on biological data has rarely been applied in mid-sized, wilderness rivers, particularly in consecutive years prior to dam removal. Concurrent snorkel and habitat surveys were conducted from the headwaters to the mouth (rkm 65-0) of the Elwha River in 2007 and 2008. This riverscape approach characterised the spatial extent, assemblage structure and patterns of relative density of Pacific salmonids. The presence of dams influenced the longitudinal patterns of fish assemblages, and species richness was the highest downstream of the dams, where anadromous salmonids still have access. The percent composition of salmonids was similar in both years for rainbow trout, Oncorhynchus mykiss (Walbaum), coastal cutthroat trout, Oncorhynchus clarkii clarkii (Richardson) $(89 \%$; 88\%), Chinook salmon, Oncorhynchus tshawytscha (Walbaum) $(8 \%$; 9\%), and bull trout, Salvelinus confluentus (Suckley) (3\% in both years). Spatial patterns of abundance for rainbow and cutthroat trout
\end{abstract}

Correspondence: Samuel Brenkman, National Park Service, Olympic National Park, 600 East Park Avenue, Port Angeles, WA 98362, USA (e-mail: sam_brenkman@nps.gov)

${ }^{1}$ Present address: Institute of Arctic and Alpine Research, University of Colorado, Campus Box 450, Boulder, CO 80309, USA. 
$(r=0.76)$ and bull trout $(r=0.70)$ were also consistent between years. Multivariate and univariate methods detected differences in habitat structure along the river profile caused by natural and anthropogenic factors. The riverscape view highlighted species-specific biological hotspots and revealed that $60-69 \%$ of federally threatened bull trout occurred near or below the dams. Spatially continuous surveys will be vital in evaluating the effectiveness of upcoming dam removal projects at restoring anadromous salmonids.

KEYWORDS: dam removal, recolonisation, riverscape, salmonid, snorkel survey.

\section{Introduction}

The placement of hydroelectric dams on rivers causes physical and biological effects that operate at multiple spatial scales (Rosenberg et al. 1997; Petts \& Gurnell 2005). Attenuated annual and seasonal discharge cycles, disrupted sediment and wood transport, altered nutrient dynamics and increased water temperatures have been widely documented in regulated rivers (Baxter 1977; Petts 1984; Hart et al. 2002). In the Northwestern United States and elsewhere, large hydroelectric projects have multiple, interacting effects on fish populations, including the decline of anadromous salmonids (Raymond 1979; Kareiva et al. 2000; Williams et al. 2005), changed evolutionary trajectories of life-history strategies (Williams et al. 2005), fish migration patterns that are altered within individual rivers (Lignon et al. 1995) and disrupted hydrological connectivity (Fullerton et al. 2010).

Dam removal has been increasingly proposed for river restoration (Bednarek 2001; Hart et al. 2002; Heinz Center 2002, Stanley \& Doyle 2003). Dam removal projects completed to date have typically involved low-head dams with structural heights of $<6$ m (Heinz Center 2002; Doyle et al. 2005). Larger dam removal projects have occurred, or are planned, at locations across the western United States, including Matilija Dam (Ventura Basin, CA), Marmot Dam (Sandy River, OR), Savage Rapids Dam (Rogue River, OR), Condit Dam (White Salmon River, WA), Klamath River Dams (OR and CA) and the Glines Canyon and Elwha Dams (Elwha River, WA). These dam removal projects provide opportunities to examine the responses of fish populations, particularly Pacific salmonids, to dam removal.

Olympic National Park (ONP), a World Heritage Site and Biosphere Reserve located on Washington State's Olympic Peninsula, contains one of the largest contiguous areas of relatively pristine habitat (373 525 ha) throughout the range of several western US coastal fish species. The park contains 12 major watersheds and some $5600 \mathrm{~km}$ of rivers and streams. However, two large hydroelectric dams (Elwha Dam and Glines Canyon Dam, 64 and $32 \mathrm{~m}$ in height, respectively) constructed in the early 1900s on the park's Elwha River eliminated access for anadromous salmonids to some $95 \%$ of the watershed.

Prior to dam construction, there were eight species of Pacific salmonids, including a large-bodied form of Chinook salmon, Oncorhynchus tshawytscha (Walbaum), with some individuals exceeding $45 \mathrm{~kg}$ (Wunderlich et al. 1994; Roni \& Quinn 1995). Estimates of historical population sizes describe a river that produced large numbers of salmonids relative to other regional rivers (Wunderlich et al. 1994; Winter \& Crain 2008). Pacific salmonids that inhabit the Elwha River are now at critically low numbers, and anadromous populations are limited to the lowest 7.5 river kilometres (rkm) below the lower dam, where there are no facilities providing upstream passage for anadromous fish.

Removal of the two Elwha River dams, scheduled to begin in 2011, will occur over a 2- to 3-year period. This project - the concurrent removal of two high dams (12 km apart) in a river that drains directly into marine waters - will be one of the largest dam removals in terms of structural height and sediment release in North America and is the second largest ecological restoration project in the National Park Service (the first being Everglades restoration). Although primarily intended to restore anadromous fish populations, the dam removal project is becoming a living laboratory for studying the ecological effects of dam removal and river restoration and could serve as an important benchmark for future dam removal projects (Duda et al. 2008).

A key to studying watershed recolonisation by Pacific salmonids after a large-scale dam removal is the collection of spatially continuous baseline information before dam removal. In the Elwha River, numerous baseline studies exist (see Winter \& Crain 2008), and recent research has characterised characterised existing fish communities and predicted the responses of Pacific salmonids to dam removal (Brenkman et al. 2008a,b; Connolly \& Brenkman 2008; Burke et al. 2008; Pess et al. 2008; Roni et al. 2008; Winans et al. 2008; Duda et al. in press). Although these studies provide useful baseline information, most were 
conducted at the site scale, within index reaches, or on a section of the river downstream of the dams, and were not spatially continuous. Because the dynamics of recolonisation will be expressed across multiple spatial and temporal scales, a riverscape perspective (Fausch et al. 2002; Torgersen et al. 2006) should prove useful in tracking vital rates, including the extent of recolonisation and species-specific interactions among recolonising anadromous fish with their resident counterparts. Many ecological frameworks (such as the River Continuum Hypothesis, intermediate disturbance hypothesis and ideal-free distribution) could be applied to explain future patterns of recolonisation following dam removal, warranting the collection of data at the riverscape scale.

Aquatic environments are inherently difficult to sample (Fausch et al. 2002), and large systems such as the Elwha River pose numerous challenges to collecting information about fish populations. The use of traditional fisheries methods is particularly challenging in the Elwha River because of prolonged periods of high flow, low water visibility from glacial melt, difficult access in rugged wilderness areas and restrictions on allowable sampling methods in National Park waters. Additionally, these challenges are compounded by the presence of migratory fishes, whose extensive movements in rivers add complexity to sampling.

A current limitation of riverscape surveys is the paucity of biological data (Carbonneau et al. 2011), particularly related to fish communities. Hankin and Reeves (1988) used spatially continuous surveys to map aquatic habitat throughout small streams, but their fish surveys were not spatially continuous. Other recent studies illustrated the use of single-pass electric fishing to map fish distributions in small streams (Bateman et al. 2005; Gresswell et al. 2006). A continuous view of fish and aquatic habitat has rarely been applied in mid-sized rivers (see Torgersen et al. 2006), particularly in wilderness rivers.

The paper describes concurrent fish and habitat surveys from the headwaters of the Elwha River to its mouth, provides baseline data prior to dam removal and facilitates inferences about salmon recolonisation following dam removal. This riverscape approach to collecting and analysing data provides a spatially continuous perspective of fishes and their associated habitats. The goal was to characterise fish assemblage structure, spatial distributions, relative abundances and densities of salmonids, and the major habitat features throughout the river during summer base flows in 2007 and 2008. Specific objectives were to: (1) determine the spatial extent of existing salmonids in the main stem Elwha River from rkm 65 to rkm 0; (2) assess the patterns of species composition, relative abundances and relative densities throughout a longitudinal gradient of consecutive channel units; and (3) assess patterns of habitat structure (e.g. habitat type, large woody debris (LWD) and substrate composition) in relation to observed fish patterns throughout the river.

\section{Study area}

The Elwha River originates in ONP on Washington's Olympic Peninsula (Fig. 1). The 6th-order (Strahler 1957) river drains $833 \mathrm{~km}^{2}$ and constitutes $19 \%$ of ONP. The Elwha River flows $72 \mathrm{~km}$ from glaciers and ice fields and descends from $1372 \mathrm{~m}$ at the headwaters to its confluence (at sea level) with the Strait of Juan de Fuca in the Pacific Ocean. The uppermost portions of the Elwha River are remote, and only a walking trail parallels the upper $45 \mathrm{~km}$. Eighty-two percent of the watershed occurs in ONP and is managed by the National Park Service as a wilderness area. The remaining portions of the river flow through State, private and tribal lands. There is road access from Glines Canyon Dam to the river mouth, a distance of $22 \mathrm{~km}$.

Three river sections were defined as the upper river above Glines Canyon Dam (hereafter UE), the middle river in-between Glines Canyon and Elwha Dams (ME) and the lower river downstream of Elwha Dam (LE). The UE is free flowing, whereas ME and LE have flows attenuated by dam operations (largely runof-the-river) for the generation of hydroelectric power. The dams have physically isolated fish populations for 98 years, eliminated access to spawning and rearing habitats for anadromous fish above rkm 7.5 and changed in-river migration patterns of steelhead trout, Oncorhynchus mykiss (Walbaum), coastal cutthroat trout, Oncorhynchus clarkii clarkii (Richardson), and bull trout, Salvelinus confluentus (Suckley).

The geomorphology of the Elwha River Basin is a series of alternating canyons and floodplains (Pess et al. 2008). The major canyons of the Elwha River from mouth to headwaters include Elwha Canyon (1.7 rkm in length), Glines Canyon (0.8 rkm), Rica Canyon (1.9 rkm), Grand Canyon (5.5 rkm), an unnamed canyon $(1.2 \mathrm{rkm})$ and Carlson Canyon (2.3 rkm) (Duda et al. 2008). Rica Canyon consists of bedrock, large boulders and high-velocity water with several cascades and waterfalls up to $1.8 \mathrm{~m}$ in height. The upstream portion of Grand Canyon contains 15 cascades and falls, and Carlson Canyon has a bedrock cataract $100 \mathrm{~m}$ in length with a $2.0 \mathrm{~m}$ 


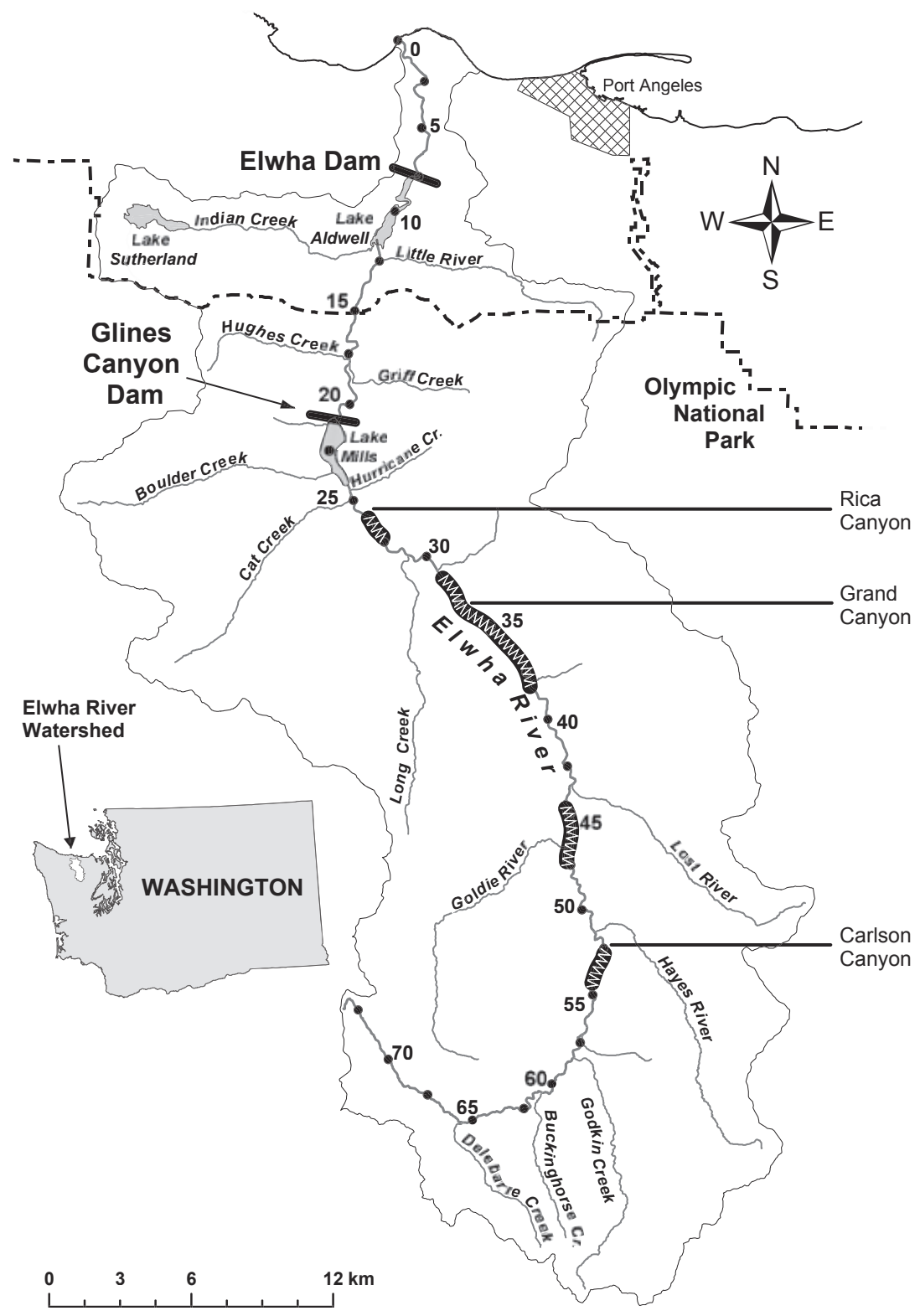

Figure 1. Map of the Elwha River watershed, Olympic Peninsula, Washington, where spatially continuous fish and habitat surveys were conducted from rkm 65 to the mouth in 2007 and 2008. Distance upstream from the river mouth is demarcated on the map by black dots annotated with river kilometres.

waterfall (Washington Department of Fisheries 1971, Brenkman et al. 2008a). Floodplain reaches occur between the alternating canyons. These depositional reaches are generally lower in gradient, contain wide gravel bars and are anastomosing channels with poolriffle morphology. There are 34 named tributaries that flow into the Elwha River, and 33 occur upstream of the dams and are not accessible to anadromous salmonids.

The mean daily discharge of the Elwha River is $42 \mathrm{~m}^{3} \mathrm{~s}^{-1}$, and annual minimum flows range from 8.5 to $14 \mathrm{~m}^{3} \mathrm{~s}^{-1}$ during summer (Curran et al. 2009). Average annual rainfall ranges from $100 \mathrm{~cm} \mathrm{yr}^{-1}$ near the mouth to over $550 \mathrm{~cm} \mathrm{yr}^{-1}$ in the headwaters (Duda et al. 2008). The estimated sediment contained in both reservoirs is 19 million $\mathrm{m}^{3}\left( \pm 3.5\right.$ million $\left.\mathrm{m}^{3}\right)$, with the majority occurring in Lake Mills, the upstream reservoir (Bountry et al. 2010). During and following dam removal, the river will naturally erode existing sediment deposits from the reservoirs.

The salmonid community in the Elwha River Basin comprises wild, natural-origin, hatchery and non- 
native fish. Salmonid species that inhabit the river downstream from Elwha Dam include Chinook salmon, coho salmon Oncorhynchus kisutch (Walbaum), pink salmon Oncorhynchus gorbuscha (Walbaum), chum salmon Oncorhynchus keta (Walbaum), sockeye salmon Oncorhynchus nerka (Walbaum), summer and winter steelhead trout, cutthroat trout and bull trout. Some of these salmonid populations have been supplemented by hatcheries since 1915 (Brenkman et al. 2008b). Non-salmonid taxa below Elwha Dam include sculpin spp. Cottus spp., threespine stickleback Gasterosteus aculeatus L., Pacific lamprey Lampetra tridentata (Richardson), redside shiner Richardsonius balteatus (Richardson), eulachon Thaleichthys pacificus (Richardson), starry flounder Platichthys stellatus (Pallas) and surf smelt Hypomesus pretiosus (Girard). Non-native brook trout Salvelinus fontinalis (Mitchill) occur below Glines Canyon Dam. Chinook salmon, steelhead, bull trout and eulachon are listed as federally threatened species under the US Endangered Species Act.

Fishery resources in the Elwha River are ecologically and culturally important and contribute to recreational, commercial and subsistence fisheries. Treaty fisheries occur for hatchery coho salmon and winter steelhead during autumn and winter. Catch-andrelease recreational fishing opportunities exist from 1 June to 31 October in ONP.

\section{Methods}

\section{Longitudinal surveys of fish species}

Spatially continuous snorkel surveys were conducted throughout $65 \mathrm{~km}$ of the Elwha River during summer low-flow in August 2007 and August and September 2008. Snorkel surveys can provide precise and reliable estimates of fish abundance (Northcote \& Wilkie 1963; Schill \& Griffith 1984; Thurow 1994) for use in quantifying the grain and extent of species distribution (Roper \& Scarnecchia 1994; Torgersen et al. 2006). Additionally, the upper Elwha River could not be surveyed effectively with other methods (e.g. electric fishing) because of difficult access. The passive nature of the technique (e.g. no handling of fish) was necessary for sampling protected fish stocks that inhabit National Park waters. The impoundments created by the dams, Lake Aldwell (4 km long) and Lake Mills (4.5 km), and canyons with white water rapids were not surveyed.

Snorkel surveys were conducted with 20 surveyors in five teams of four from 21 to 24 August 2007 and from 26 to 29 August and 4 to 9 September 2008. As a result of high flows in August 2008, the latter 3 days of the survey were completed in September (i.e. for a span of 15 days instead of 5 days in 2007). Surveyors were professional biologists experienced in snorkelling techniques and fish identification. To access remote river sections, pack mules were used to carry and distribute field and camping equipment. Prior to the week-long surveys, aerial reconnaissance was conducted in a Cessna 172 to map log jams and other hazards along the river, while foot surveyors flagged upstream and downstream ends of each canyon.

In each team, two divers drifted downstream on each side of the river and counted individuals of each species. In wide sections of LE and ME, a third diver was used to sample the entire channel and to count fish in side channels. Divers recorded length classes of bull trout, cutthroat trout and rainbow trout in categories of $0-10,>10-20,>20-30$ and $>30 \mathrm{~cm}$. Counts for cutthroat trout and O. mykiss (rainbow trout or juvenile steelhead) were combined because of the difficulty in distinguishing between these species and are hereafter referred to as trout. Young-of-the-year salmonids were noted but are not presented. When fish were observed in large aggregations or near wood jams, divers made two passes in their respective lanes and averaged counts when necessary. Divers recorded data at $\approx 100$-m intervals to compare observations and avoid duplication of counts.

Although the extent of the snorkelling surveys was the same in 2007 and 2008, the grain differed between years. In 2007, fish counts were recorded in 21 reaches that were $1-8 \mathrm{~km}$ in length and only limited habitat data were collected. Reach boundaries were based on easily identifiable geographic features (i.e. bridges or tributary confluences) on topographic maps and aerial photographs. In 2008, fish counts and aquatic habitat descriptions were recorded for every channel unit.

\section{Longitudinal surveys of aquatic habitat}

In 2008, a spatially continuous habitat survey was conducted concurrent with the fish survey. In coordination with the divers counting fish, two habitat surveyors walked downstream and measured physical habitat variables including channel type (main, secondary or side channel), habitat type (riffle, glide-like riffle, glide-like pool and pool, in order of decreasing velocity), channel-unit length and wetted width. Wetted width was averaged from three measurements taken at 25,50 and $75 \%$ of the distance from the upstream end of the unit. All distances were measured using a laser range finder. Hand-held global positioning system (GPS) units were used to map the longitudinal boundaries of each channel unit. 
Riffles longer than $200 \mathrm{~m}$ were subdivided and georeferenced at 200-m intervals. Field observations of tributary junctions and other landmarks were used as geographic reference points when satellite reception was limited. The GPS track-log function enabled temporally and spatially continuous collection of position and odometer data.

Cover and substrate were recorded for each channel unit including extent of overhanging vegetation, boulders, and number and area of log jams in each channel unit. The percent of river bank habitat with vegetation overhanging the wetted channel within $30 \mathrm{~cm}$ of the water surface was visually estimated. The percent of the channel-unit surface area covered by boulders $(>256 \mathrm{~mm}$ ) was also visually estimated. Wood pieces $>10 \mathrm{~cm}$ in diameter breast height and aggregations (i.e. $\log$ jams) were counted, and their surface area was measured. The percentage of dominant and subdominant substrate types was visually estimated by the two divers according to categories in Cummins (1962): bedrock (including hardpan clay), boulder ( $>256 \mathrm{~mm}$, including riprap), cobble $(64-256 \mathrm{~mm})$, gravel $(2-$ $64 \mathrm{~mm})$, sand $(<2 \mathrm{~mm})$, silt $(<0.6 \mathrm{~mm})$ and organic debris. The snorkelers estimated mean and maximum depth $(\mathrm{cm})$ of each channel unit.

\section{Geographical Information System (GIS) methods and data analysis}

Linear referencing methods were used in ArcGIS (ESRI 2006) to map fish counts and channel units along the $65 \mathrm{~km}$ of the Elwha River. The National Hydrography Dataset (NHD 2009) was used for mapping the main stem Elwha River in the GIS, but recent aerial photographs (2006 and 2008) indicated that updates to this map layer were required because of channel migration (see Draut et al. 2010 for rates) that had occurred since the 1950s when the US Geological Survey hydrography layer (1:24 000-scale topographic quadrangles) was created. Modifications of the NHD hydrography were made using a combination of aerial photographs, GPS track-logs and field notes from the 2008 field survey. In the GIS, channel units and reaches were georeferenced based on cumulative distance upstream from the river mouth. This process involved digital rectification (i.e. dynamic segmentation) of channel-unit lengths, relative distances from landmarks (e.g. tributary junctions and bridges) and GPS waypoints (sensu Radko 1997).

Longitudinal patterns in fish abundance and aquatic habitat throughout the Elwha River were analysed by plotting the data vs distance upstream. Reaches $(n=21)$ were used to compare patterns of fish abundance between years because the 2007 survey was conducted at a coarser scale than in 2008. To evaluate spatial patterns of fish distribution, within each reach, the relative abundance (i.e. the number of a given species divided by the total number of all fish observed) was calculated and plotted against distance upstream for 3-D visualisation in GIS. The relative density, $D_{\mathrm{r}}$, was also calculated for each species and size class to compare patterns of abundance among reaches. $D_{\mathrm{r}}$ is defined as $D_{\mathrm{r}}=\left[\left(f_{\mathrm{i}} / l_{\mathrm{i}}\right) /\left(f_{\mathrm{t}} / l_{\mathrm{t}}\right)\right]-1$, where $f_{i}$ is the number of fish in reach $i, f_{\mathrm{t}}$ is the total number of fish in all reaches, $l_{\mathrm{i}}$ is the length of reach $i$ and $l_{t}$ is the total length of river surveyed. Normalised relative density was used to compare longitudinal patterns of $D_{\mathrm{r}}$ between years and was calculated by dividing $D_{\mathrm{r}}$ in each reach by the maximum $D_{\mathrm{r}}$ for all reaches. Positive and negative values of normalised relative density indicate densities that are, respectively, above and below the average density for the entire river.

Aquatic habitat data from summer 2008 were recorded for each channel unit, but to facilitate analysis throughout the entire $65 \mathrm{~km}$ of the Elwha River, data were summarised in $1-\mathrm{km}$ bins as: (1) percentages based on channel-unit length (pool and riffle habitat, and gravel and boulder substrate); (2) means weighted by proportionate channel-unit length (wetted width and area of LWD jams); or (3) total count (LWD jams). For all longitudinal analyses, sidechannel attributes were included in the calculations of fish abundance and aquatic habitat characteristics for the reaches and $1-\mathrm{km}$ bins to which they were adjacent. Custom scripts developed in the $\mathrm{R}$ statistical package (R Development Core Team 2009) were used to plot longitudinal profiles of aquatic habitat variables.

\section{Spatially continuous fish and habitat relationships}

Several steps were used to relate fish species abundance to physical habitat variables collected in 2008. Principal components analysis (PCA) with joint points in PC-ORD (MjM Software, Gleneden Beach, OR) was used to reduce a subset of habitat variables to two orthogonal variables (linear combinations of the original variables) describing the river channel units. This allowed graphic analysis of the relatedness of $44,1-\mathrm{km}$ bins in different floodplain sections above, between and below the dams, as well as to quantify variables responsible for differences. For continuity with the 2008 survey results, channel-unit scores were averaged within each of the 2008 bins $(n=44)$ for 11 continuous habitat variables, which ensured a minimum ratio of variables to observations recommended for ordination. Skewed variables were 
square-root-transformed (i.e. number of jams and jam area), and then the data matrix was normalised to eliminate differences in measurement scale.

Next, species density (fish $\mathrm{km}^{-1}$ ) was used as the response variable, and the 11 stream habitat characteristics were used as independent variables in a linear modelling approach. Akaike's Information Criterion, adjusted for small sample sizes (AICc), was used to determine which linear regression model best fits the data (Burnham \& Anderson 2002). The difference between the AICc of a candidate model and the one with the lowest AICc provided the ranking metric ( $\triangle \mathrm{AICc})$. Generally speaking, $\triangle \mathrm{AICc}$ between 0 and 4 indicates substantial support for a model being as good as the best approximating model, $\triangle \mathrm{AICc}$ between 4 and 7 represents less support and $\triangle \mathrm{AICc}$ of $>7$ indicates very little support for a candidate model relative to the best model (Burnham \& Anderson 2002).

Akaike weights $\left(w_{i}\right)$ were calculated, representing the strength of evidence in favour of model $i$ being the best model. The ratio of Akaike weights $\left(w_{i} / w_{j}\right)$ represents the plausibility of the best-fitting model compared with other models (Burnham \& Anderson 2002). Models with an evidence ratio of 10 or less were considered plausible. If models were not the best model based on the preceding criteria, then models within three AICc were considered competing models and results were averaged to determine the maximum likelihood estimate for the intercept and each of the independent variables that were part of the models (Burnham \& Anderson 2002; Haring \& Fausch 2002).

\section{Results}

The distributions, assemblage structure, abundances, normalised relative densities and length classes of Pacific salmonids in the Elwha River in 2007 and 2008 were summarised and analysed by continuously mapped habitat variables in 2008. River discharge (USGS stream-flow gauging station 12045500) during snorkel and habitat surveys ranged from 14.8 to $16.2 \mathrm{~m}^{3} \mathrm{~s}^{-1}$ and from 12.1 to $24.3 \mathrm{~m}^{3} \mathrm{~s}^{-1}$ in 2007 and 2008, respectively. In August 2008, a large rain event caused episodic increases in river discharge that reduced water visibility. A total of $6 \mathrm{~cm}$ of precipitation $(90 \%$ of the monthly total) occurred immediately prior to, and during, the survey in the upper Elwha River.

\section{Fish distribution and assemblage structure}

Trout and bull trout were distributed from the upstream extent of the survey (rkm 65.2) to the mouth (rkm 0), while Chinook salmon and pink salmon were confined to LE because of the Elwha Dam (Fig. 2). In 2007, 7312 trout, 687 adult Chinook salmon, 215 bull trout and 26 pink salmon were counted throughout the Elwha River (8240 total fish). In 2008, 3218 trout, 316 adult Chinook salmon and 118 bull trout (3652 total fish) were observed. Non-native brook trout (LE and ME only), sculpin (spp.; LE and ME only), threespine stickleback (LE) and starry flounder (LE) were observed in low numbers each year.

The longitudinal fish assemblage patterns revealed that species richness was the lowest in UE (above Glines Canyon Dam) and highest in LE (Fig. 2). Trout were the dominant fish throughout the river and comprised $89 \%$ and $88 \%$ of the total fish assemblage in 2007 and 2008, respectively. The fish species assemblage also comprised Chinook salmon $(8 \%$ in 2007; $9 \%$ in 2008), bull trout (3\% in both years) and pink salmon $(<1 \%$ in 2007 only). The highest total and relative abundances of bull trout were immediately upstream of Lake Mills and near the headwaters in both years (Fig. 2). Of the total numbers of bull trout observed, $60 \%$ and $69 \%$ were observed from Rica Canyon downstream to the river mouth in 2007 and 2008, respectively. The patterns of abundances for trout and bull trout were correlated between years despite the differences in river flows in 2007 and 2008 (Pearson's correlation, $r=0.70$ for bull trout and $r=0.76$ for trout, $P<0.001$, Fig. 3).

\section{Relative densities and length classes}

Patterns of normalised relative densities of trout and bull trout varied among LE, ME and UE and between years in 2007 and 2008 (Fig. 4a, b). Analysis of fish among LE, ME and UE revealed a total of 295, 227 and 102 trout $\mathrm{km}^{-1}$ and 4,6 and 4 bull trout $\mathrm{km}^{-1}$, respectively, in 2007. Densities of 143, 159 and 25 trout $\mathrm{km}^{-1}$, and 1,3 and 3 bull trout $\mathrm{km}^{-1}$ were observed among river sections in 2008 (Table 1).

The highest normalised $D_{\mathrm{r}}$ of trout, for all length classes combined, occurred downstream of the two reservoirs ( $\mathrm{rkm} 22-0)$ and was the lowest immediately upstream of Lake Mills (Fig. 4a). Normalised $D_{\mathrm{r}}$ of small trout $(10-20 \mathrm{~cm})$ generally varied between the 2 years throughout the river (Fig. 4a). Normalised $D_{\mathrm{r}}$ of larger trout $(20-30 \mathrm{~cm} ;>30 \mathrm{~cm})$ was the highest immediately downstream of each dam (Fig. 4a).

Normalised $D_{\mathrm{r}}$ varied along the longitudinal gradient of the Elwha River in 2007 and 2008 (Figs 4a, b). The highest normalised $D_{\mathrm{r}}$ of bull trout, for all length classes combined, occurred upstream of Lake Mills and immediately downstream of Glines Canyon Dam 

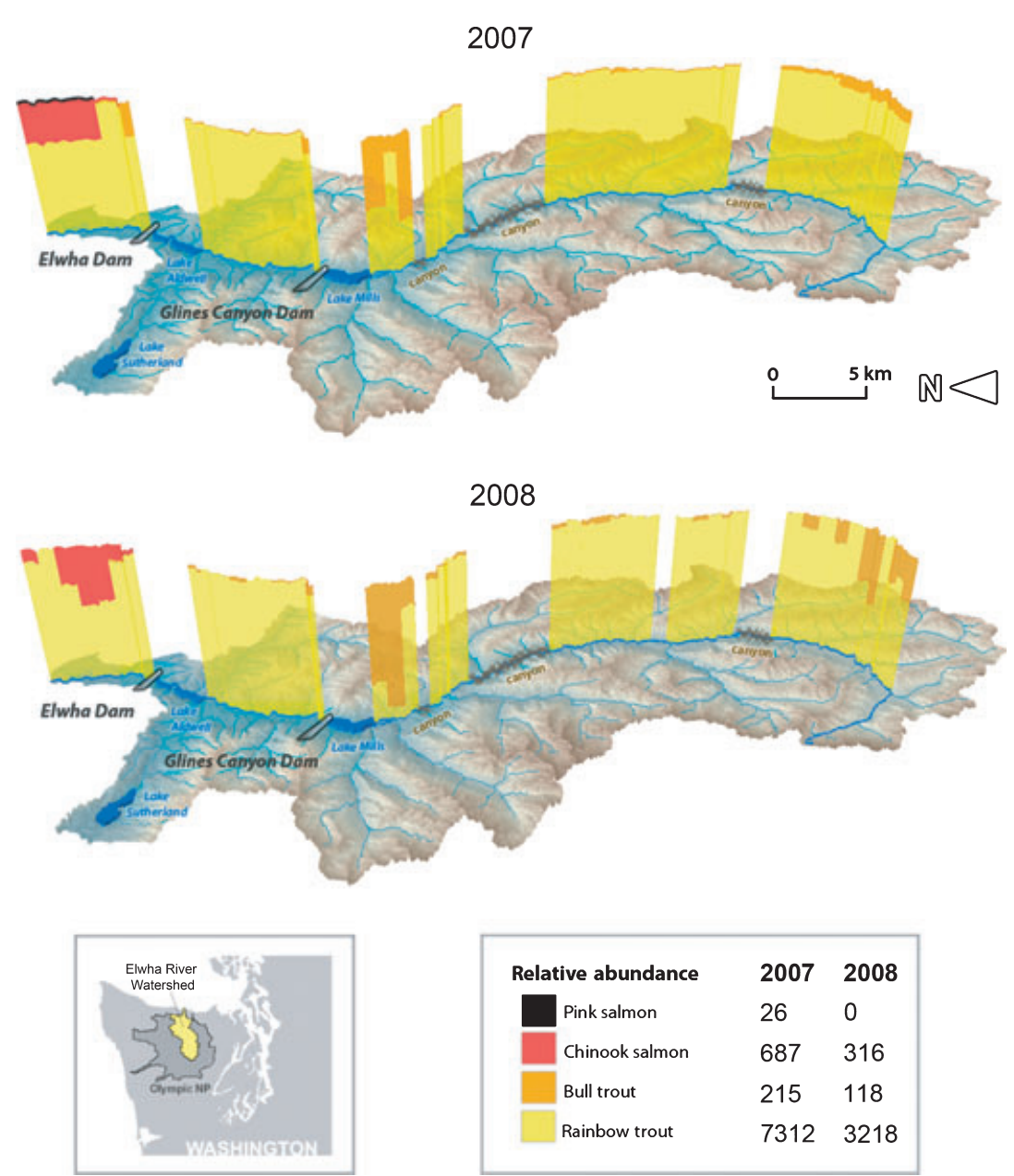

\begin{tabular}{|lll|}
\hline Relative abundance & $\mathbf{2 0 0 7}$ & $\mathbf{2 0 0 8}$ \\
\hline Pink salmon & 26 & 0 \\
Chinook salmon & 687 & 316 \\
Bull trout & 215 & 118 \\
Rainbow trout & 7312 & 3218 \\
\hline
\end{tabular}

Figure 2. Distribution and relative abundance of salmonids in the Elwha River based on spatially continuous snorkel surveys conducted in the summers of 2007 and 2008 from rkm 65 to the river mouth. Stacked bars indicate the relative abundance (i.e. proportion of total abundance) for each species. The inset table provides total counts of fish by species in 2007 and 2008.

(Fig. 4b). The longitudinal patterns of high and low $D_{\mathrm{r}}$ of bull trout were consistent among the three size classes from the headwaters to the mouth. Normalised $D_{\mathrm{r}}$ patterns were also consistent between the 2 years (Fig. 4b). There was relatively low normalised $D_{\mathrm{r}}$ of large bull trout $(>30 \mathrm{~cm})$ throughout the UE (Fig. 4b).

\section{Distribution of habitat variables along a longitudinal gradient}

Differences were observed in the longitudinal distribution of major habitat features in the Elwha River from $\mathrm{rkm} 65.2$ to $\mathrm{rkm} 0$ in 2008. There were 316 individual channel units throughout the river, and there were distinct differences among UE, ME and LE (Table 1). The UE was the longest section surveyed $(31 \mathrm{~km}$ surveyed) and had the highest gradient, the lowest mean wetted width and the highest number of named tributaries $(n=27)$ among river sections (Table 1). The UE also had the highest percentage of riffles by area and the lowest percentage of pools by area. Additionally, the UE had the highest LWD count and the highest LWD area per $\mathrm{km}$ (Table 1).

The section of the Elwha River between the two dams (ME) was the widest section (mean wetted width $=39 \mathrm{~m})$ and had six tributaries. The number of channel units was the lowest in this section, but the channel units were the deepest for each of the habitat types (Table 1). This section of river had limited amounts of LWD and contained the lowest number and total area LWD.

The section downstream of Elwha Dam (LE) was the shortest section surveyed $(7.2 \mathrm{~km})$, had only one 


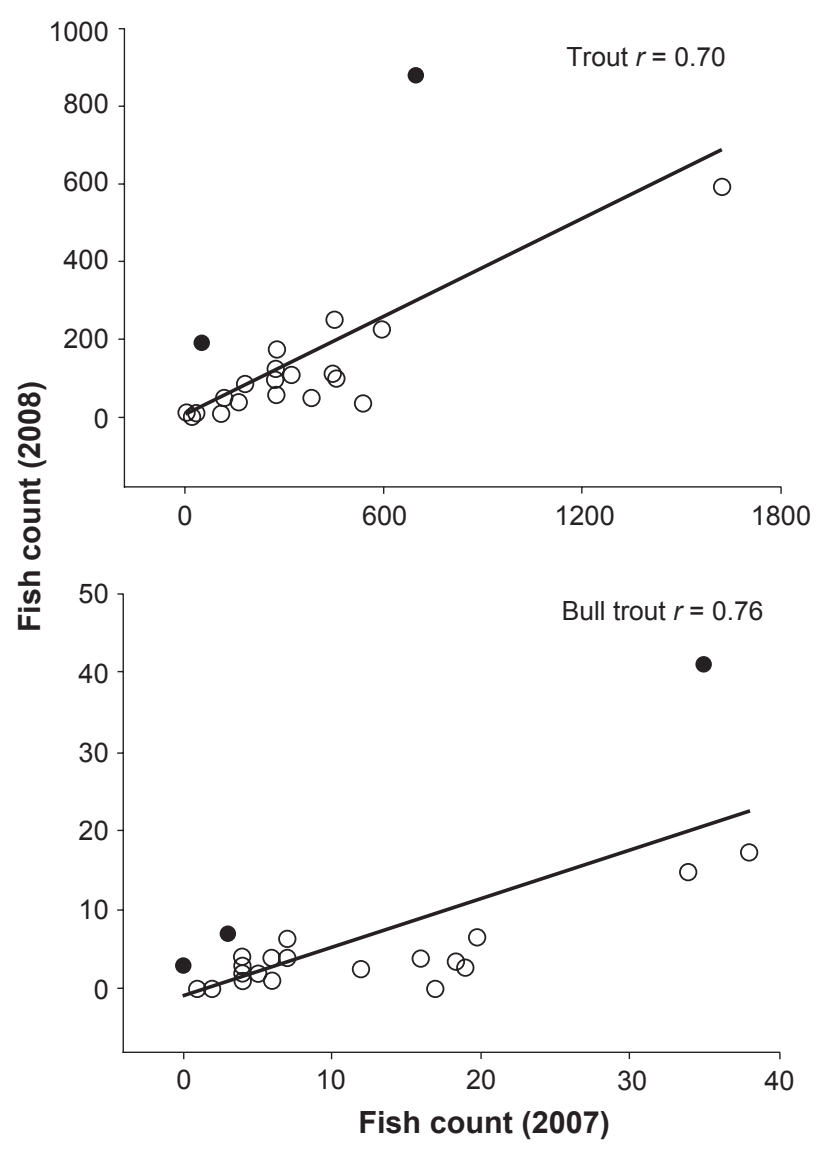

Figure 3. Pearson correlations of total trout (rainbow and cutthroat trout combined) and bull trout counts by reach $(n=21)$ in the Elwha River in 2007 and 2008. Solid black circles represent counts that were higher in 2008 than 2007.

tributary and had the lowest gradient. This section had the highest percent area of pools and glide-like pools and the lowest percent area of riffles and glide-like riffles. The mean depths of pools and riffles were lowest compared with the upper and middle river sections. The lower river had high amounts of LWD including the highest mean area of $\log$ jams and highest area of jams km ${ }^{-1}$ (Table 1; Fig. 5g).

The wetted channel width increased from the headwaters to the river mouth, as did percent pool habitat (Fig. 5b). Longitudinal patterns of riffles (total length, $\%$ ) varied among UE and ME, and percentages were generally lowest in LE.

The UE and areas immediately upstream of Lake Mills were dominated by gravel substrates (Fig. 5d). The percentage of gravel substratum was low in large portions of the ME, LE and immediately upstream of rkm 25 (Fig. 5d). Boulders were the dominant substrate in the ME and LE below the dams. The total abundance of LWD was the highest in the headwaters although the peak abundance of wood occurred in LE (Fig. 5f).

The PCA extracted two significant axes $(P<0.01$ based upon randomisation tests) that described $57 \%$ of the variance. Increases along the first principal component axis corresponded to higher number of $\log$ jams and percent gravel substrate, whereas decreases along this axis corresponded to higher percent boulder substrate, higher wetted width, greater channel-unit area and greater channel-unit depth. Correspondingly, sites in LE and ME were separated from sites in UE along this axis (Fig. 6). The second principal component axis differentiated units with higher percentages of cobble from those units with low percentages of sand and silt, but only explained $17 \%$ of the variation.

\section{Spatially continuous fish and habitat relationships}

There were consistent positive associations between trout and bull trout abundances and habitat unit area, substrate type, instream cover and river section variables. Almost all the trout models (total and each size class) with the best AICc scores included total habitat unit area (Table 2). The amount of boulder area or amount of instream boulder cover, large wood area or the number of log jams, and river section were in the majority of the best trout candidate models (Table 2). Total habitat unit area and gravel (\%) were in all the bull trout candidate models with the best AICc scores (Table 3). River section and the total number of $\log$ jams were the only other independent variables that were in the bull trout candidate models with the best AICc scores.

The relationship between trout $\mathrm{km}^{-1}$ and total habitat area and boulders (\%) was always positive, while there was always a negative correlation between trout $\mathrm{km}^{-1}$ and river section (Table 2). Large wood area and the number of log jams were, for the most part, positively associated with trout $\mathrm{km}^{-1}$, while instream boulders $(\%)$ were for the most part negatively associated with trout $\mathrm{km}^{-1}$ (Table 2). Total habitat area, river section and gravel (\%) were positively correlated with trout $\mathrm{km}^{-1}$, while the number of $\log$ jams was negatively correlated with bull trout $\mathrm{km}^{-1}$ (Table 3).

\section{Discussion}

No previous studies have used a similar riverscape approach to describe spatially continuous fish and habitat relationships prior to dam removal, and 

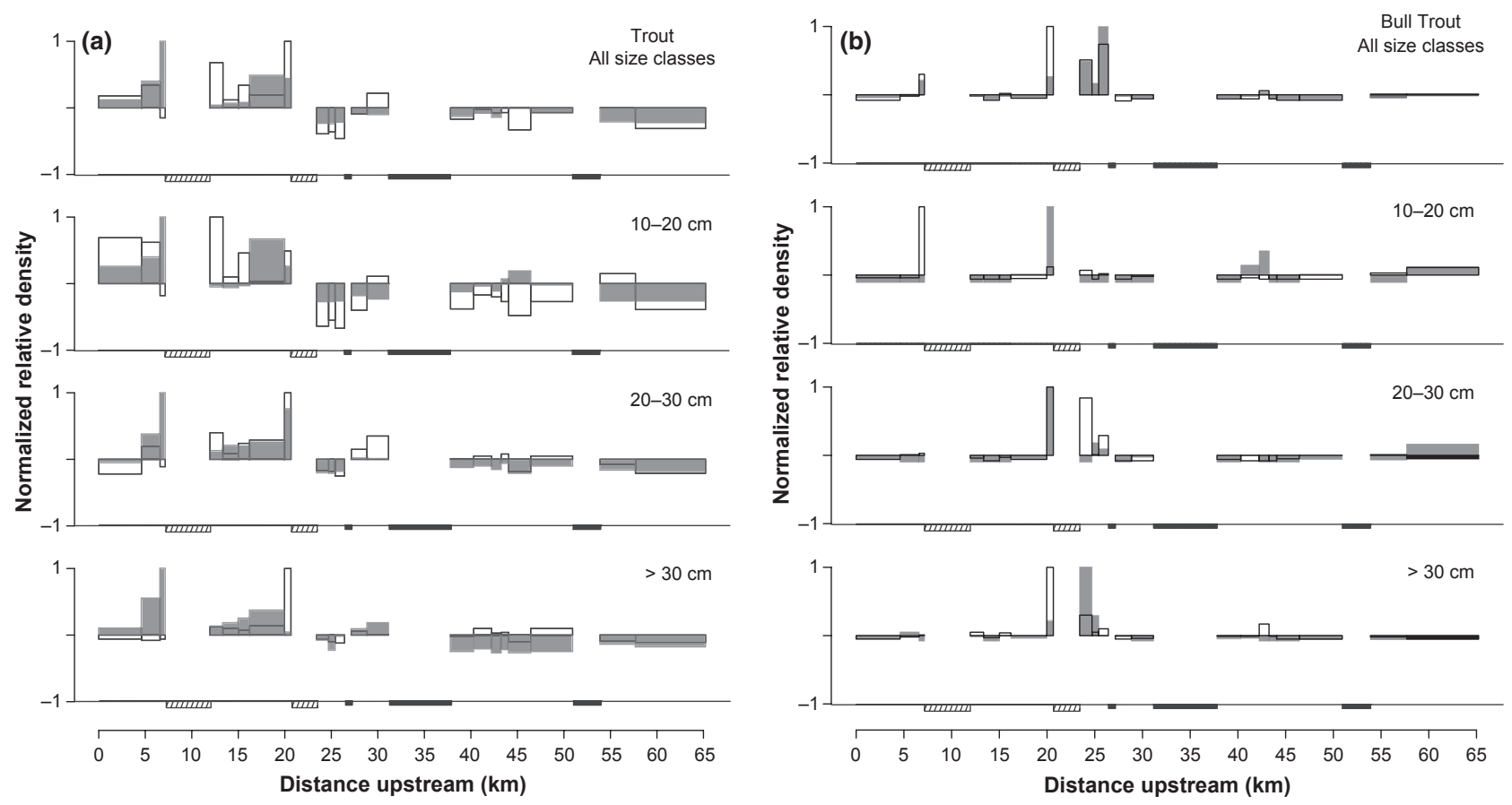

Figure 4. Normalised relative density of (a) trout and (b) bull trout length classes $(10-20 \mathrm{~cm} ;>20-30 \mathrm{~cm}$; $>30 \mathrm{~cm})$ throughout the Elwha River based on snorkel surveys in the summers of 2007 (grey bars) and 2008 (white bars). Positive and negative values indicate densities that are above and below, respectively, the average density for the entire river. Reservoirs and other unsurveyed sections are indicated along the $x$-axis with hatching and thick black lines, respectively. Distance upstream corresponds to river kilometres in Fig. 1.

consecutive year studies of longitudinal patterns of riverine fish and aquatic habitats are rare (Labbe \& Fausch 2000; Gresswell et al. 2006). The riverscape approach (Fausch et al. 2002; Torgersen et al. 2006) provided a spatially comprehensive view of the fish assemblage in the Elwha River and characterised physical habitat conditions from the headwaters to the mouth in two consecutive years. These spatially continuous surveys provided ecological insights based on data visualisations, which establish baselines of the Elwha fish community and important habitat variables prior to a historic dam removal project.

Using a riverscape approach, baseline information was collected on fish at the species, population and assemblage levels and observed patterns allowing analysis at the channel unit, river reach, valley segment or entire river scales (Frissell et al. 1986). This approach will be instrumental in understanding the recolonisation and rebuilding of salmon populations, a dynamic process that will be influenced across complex biological hierarchies and multiple spatial scales (Wiens 2002; Allan 2004).

The longitudinal analysis of fish patterns identified biological hotspots for different fish species. The spatial discontinuity of fish assemblages and abun- dance is not atypical of river networks (Benda et al. 2004; Kiffney et al. 2006; Rice et al. 2008; Torgersen et al. 2008). The network dynamic hypothesis and other more empirically based studies have suggested that areas such as tributary junctions and transitional areas between confined and unconfined portions of a drainage network can be areas of accumulation for biota, sediment, wood and nutrients (Baxter et al. 1999; Benda et al. 2004; Kiffney et al. 2006). Mapping patterns of relative abundance in GIS revealed that most $(60-69 \%)$ of the federally threatened bull trout were observed near or below the reservoirs, areas that will be highly influenced by increased sediment levels during dam removal. The identification of these biological hotspots will be important in guiding future monitoring efforts, both during and following dam removal. In the face of much uncertainty about salmonid recolonisation, as well as limited monitoring budgets, it is important to know where to focus future monitoring efforts. Also, as a consequence of expected high turbidity levels during dam removal, the data on bull trout distribution and patterns of abundance will prove valuable for planning mitigation and protection strategies of this threatened fish species during dam removal. 
Table 1. Physical and biological characteristics of the lower (LE), middle (ME) and upper (UE) Elwha River based on snorkel and habitat surveys in summer 2008

\begin{tabular}{|c|c|c|c|}
\hline & \multicolumn{3}{|c|}{ Elwha River section } \\
\hline & LE & $\mathrm{ME}$ & UE \\
\hline \multicolumn{4}{|l|}{ General characteristics } \\
\hline Section boundaries & $\begin{array}{l}\text { Downstream of } \\
\text { Elwha Dam }\end{array}$ & $\begin{array}{l}\text { Between Elwha and } \\
\text { Glines Canyon dams }\end{array}$ & $\begin{array}{l}\text { Upstream of Glines } \\
\text { Canyon Dam }\end{array}$ \\
\hline River km (rkm) & $0-7.9$ & $7.9-21.9$ & $21.9-65.7$ \\
\hline Number of named tributaries* & 1 & 6 & 27 \\
\hline Elevation range $(\mathrm{m})$ & $0-62$ & $62-184$ & $184-1372$ \\
\hline Natural wood recruitment & Altered by dams & Altered by dams & Yes \\
\hline Natural sediment recruitment & Altered by dams & Altered by dams & Yes \\
\hline \multicolumn{4}{|l|}{ Habitat survey results } \\
\hline Kilometres surveyed $^{\dagger}$ & 7.4 & 8.6 & 31.9 \\
\hline Mean wetted width (m; SD) & $29(19)$ & $39(12)$ & $19(9)$ \\
\hline Channel slope $(\% ;$ SD) & $0.4(0.11)$ & $0.8(0.36)$ & $1.3(0.49)$ \\
\hline Number of pool units & 20 & 11 & 49 \\
\hline Number of glide-pool units & 17 & 7 & 31 \\
\hline Number of glide-riffle units & 11 & 9 & 42 \\
\hline Number of riffle units & 19 & 17 & 83 \\
\hline$\%$ Pool units by length & $30(31)$ & $25(17)$ & $24(11)$ \\
\hline$\%$ Glide-pool units by length & $26(39)$ & $16(14)$ & $16(15)$ \\
\hline$\%$ Glide-riffle units by length & $16(8)$ & $20(29)$ & $20(21)$ \\
\hline$\%$ Riffle units by length & $28(22)$ & $39(40)$ & $40(53)$ \\
\hline Mean pool depth (m; SD) & $1.24(0.87)$ & $2.05(0.70)$ & $1.43(0.49)$ \\
\hline Mean glide-pool depth (m; SD) & $1.2(0.45)$ & $1.21(0.36)$ & $0.96(0.41)$ \\
\hline Mean glide-riffle depth (m; SD) & $0.64(0.15)$ & $0.77(0.22)$ & $0.64(0.31)$ \\
\hline Mean riffle depth (m; SD) & $0.50(0.37)$ & $0.90(0.23)$ & $0.60(0.26)$ \\
\hline LWD jams (count) & 38 & 8 & 197 \\
\hline LWD jam area $\left(\mathrm{m}^{2}\right)$ & 11570 & 477 & 12597 \\
\hline LWD km $\mathrm{km}^{-1}$ & 5.1 & 0.9 & 6.8 \\
\hline \multicolumn{4}{|l|}{ Snorkel survey results } \\
\hline ONMY km ${ }^{-1}(2007 / 2008)$ & $295 / 143$ & $227 / 159$ & $102 / 25$ \\
\hline SACO km ${ }^{-1}(2007 / 2008)$ & $4 / 1$ & $6 / 3$ & $4 / 3$ \\
\hline
\end{tabular}

*From Williams et al. 1975.

${ }^{\dagger}$ Excluding side channels, canyons $(10.4 \mathrm{~km})$ and reservoirs $(7.6 \mathrm{~km})$.

"Excluding canyon sections.

${ }^{\S}$ Large woody debris (LWD).

\section{Spatially continuous fish and habitat relationships}

Longitudinal patterns of fish assemblages were most strongly influenced by the presence of the two dams. The highest species richness occurred downstream of Elwha Dam where salmon still occur, whereas species richness was the lowest above Glines Canyon Dam where only isolated populations of trout and bull trout occur. Although the spatial distribution of local population size varied longitudinally, the patterns were largely consistent between years, despite the different hydrological conditions encountered during the two surveys. There were high correlations of trout and bull trout counts between 2007 and 2008, despite a greater than twofold difference in total fish observed in each year. The percent composition was similar for trout, Chinook salmon and bull trout throughout the $65 \mathrm{~km}$ of river.

Survey results revealed that trout were ubiquitous from the headwaters to the mouth and dominated the fish assemblage in both years. There was a difference between fish densities upstream and downstream of the dams. The high densities of trout downstream of Elwha Dam (LE) may be partially explained by the presence of wild and residual hatchery steelhead smolts in that section of the river. A total of 76500 and 56500 hatchery smolts were released in May 2007 and 2008, respectively.

The high numbers of $O$. mykiss throughout the Elwha River have important implications for steelhead 

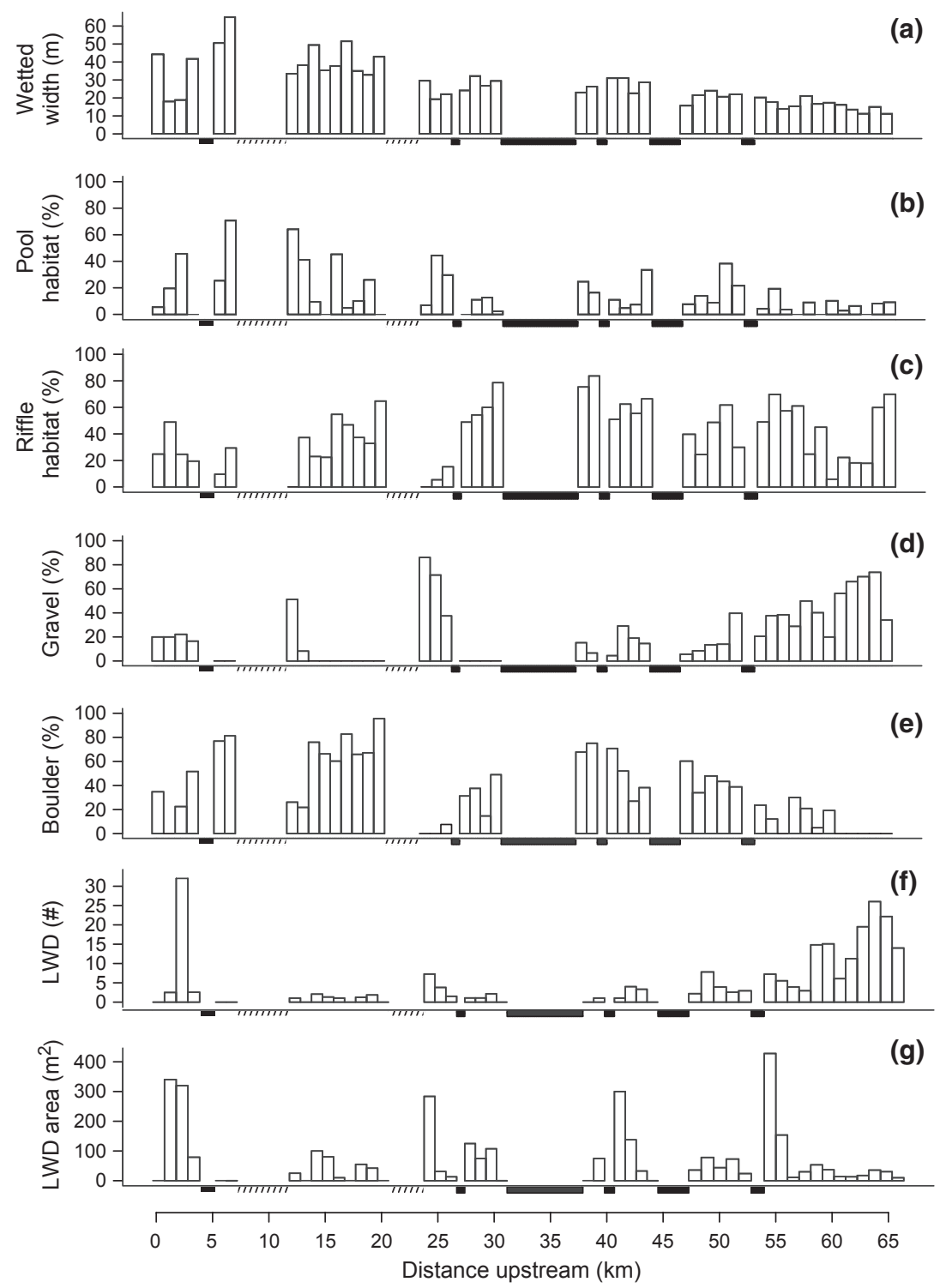

Figure 5. Longitudinal patterns of aquatic habitat in the Elwha River in summer 2008. Mean wetted width (a), percentages of pool (b) riffle (c) habitat and gravel (d) boulder (e) substrate, number (f), and mean area (g) of large woody debris (LWD) jams are summarised in 1-km bins. Reservoirs and other unsurveyed sections are indicated along the $x$-axis with hatching and thick black lines, respectively. Distance upstream corresponds to river kilometres in Fig. 1.

restoration and recolonisation, particularly because wild residents can contribute substantially to steelhead populations (Christie et al. 2011). It is anticipated that O. mykiss from the upper river will resume anadromy, contribute to recolonisation and interact with returning populations of summer and winter steelhead after dam removal (Brenkman et al. 2008a).

The patterns of physical habitat variables, from both univariate and multivariate perspectives, highlighted the effects of both natural (fluvial and geomorphic) and anthropogenic (dams and reservoirs) drivers.
River width and depth increased steadily from the headwaters to the mouth because of increasing drainage basin size. This resulted in channel units having, on average, greater area, depth and width in the lower portions of the watershed, which has a role in structuring fish assemblage patterns (Gorman \& Karr 1978). Substrate composition also varied naturally along the longitudinal profile of the river. Above the upper dam, gravel showed a nearly monotonic decrease from rkm 65 to 37, with an inverse increase in boulder cover. However, there were also impacts of 


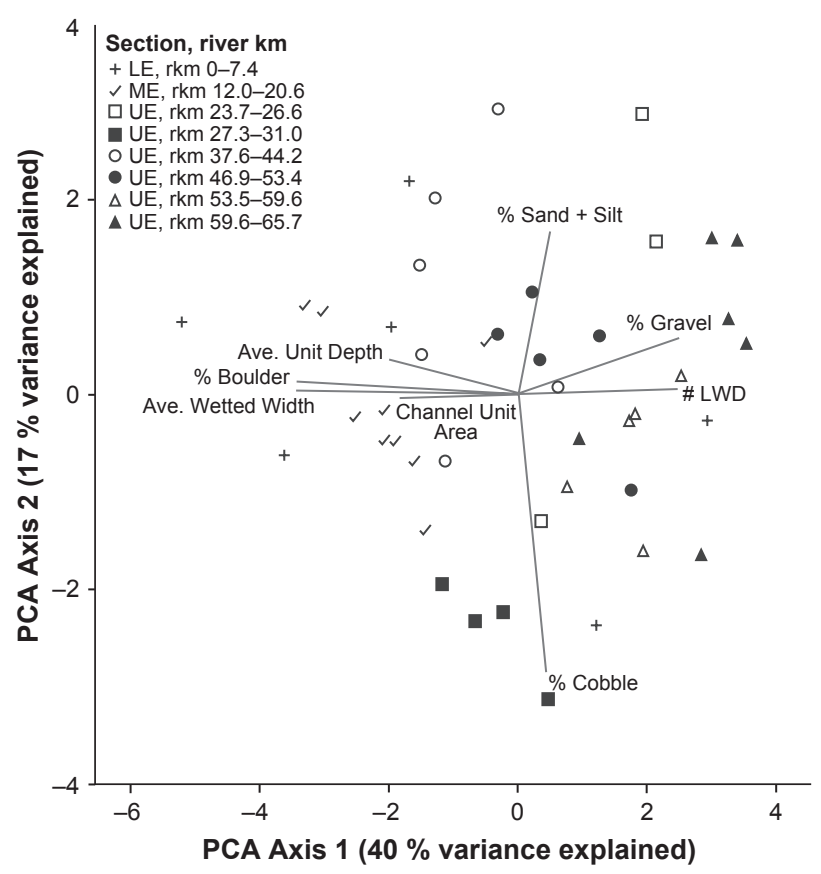

Figure 6. Principal components analysis of habitat variables in the Elwha River in summer 2008. Points in the ordination represent floodplain segments in habitat space. The coding for individual floodplain segments is provided in the legend, which indicates the section (LE, ME and UE; see Fig. 1) and the floodplain segment location in river kilometres. Vectors of the joint plot overlaid on the ordination indicate the orientation and magnitude of correlations of habitat variables with each axis.

the dams, especially in ME, as the dominance of boulders and paucity of gravel below the Glines Canyon Dam demonstrated. In LE below Elwha Dam, there was a less dramatic decrease in gravel, as this section of river still receives sand and gravel inputs from eroding bluffs and terraces, as well as interactions with the floodplain. Previous studies showed that the Elwha River below each dam is dominated by boulders and cobbles (Pohl 2004; Morley et al. 2008). Kloehn et al. (2008) and Draut et al. (2010) also showed reduced levels of channel migration in ME compared with LE, indicative of the increased channelisation and bed armouring in ME. The increase in boulderdominated substrate has decreased spawning habitat available for anadromous salmonids and contributed to population declines (Pess et al. 2008).

The amount and area of LWD also showed different distribution patterns across the riverscape profile. There were more pieces of LWD at higher elevations in UE near the headwaters compared with the rest of the river. However, these were often single pieces rather than large accumulations of LWD, with some exceptions near the transitional reaches between floodplain channels and canyons. This could, in part, be explained in the UE by relatively larger average wood piece size and a relatively smaller wetted channel width. There were smaller LWD jam area and lower density in the ME because of wood entrainment in Lake Mills reservoir and reduced wood recruitment from this river section. Additionally, the ME has a large number of smaller, unsurveyed floodplain channels that contain wood accumulations. The distribution of wood in the LE has been much influenced by human activity through historical removal and recent installation of engineered $\log$ jams, as well as natural wood recruitment (Pess et al. 2008). The size of LWD accumulations is important as the larger accumulations have a greater and longer-lasting impact on fish habitat, retain higher amounts of organic debris and sediment and exert greater hydrological control by creating larger, longer-lasting scour pools (Abbe \& Montgomery 1996). Smaller pieces, on the other hand, lead to finer scale and temporally transient effects during low flows and are transported downstream during larger flows (Hyatt \& Naiman 2001).

Habitat area, percent overhanging vegetation and boulder cover, and streambed substrate size were significantly correlated with the abundance of trout and bull trout in the Elwha River. Bull trout persistence has previously been positively correlated with an increase in habitat area (Watson \& Hillman 1997; Dunham \& Rieman 1999). For other adult salmonid species, such as pink, chum and Chinook salmon, occurrence and abundance patterns have also been correlated to increasing habitat area in Alaska (Pess 2009) and throughout the Pacific Rim (Liermann et al. 2010). An increase in habitat area alone, without a change in habitat type or increased resilience to disturbance, can increase the occurrence and abundance of animals (Connor et al. 2000). The amount of in-channel cover, regardless of type (e.g. boulder, wood, depth), has consistently been shown to be positively correlated with salmonid fish densities (Shirvell 1990; Fausch 1993; Beechie et al. 2005). Oncorhynchus mykiss prefer boulder, overhead cover (Shirvell 1990; Fausch 1993) and wood cover (Beechie et al. 2005). The correlation between cover types and trout densities may, in part, be spurious and the result of competition with other species, or an artefact of their ability to occupy higher-velocity habitats (Bisson et al. 1988).

Although conducted in a remote wilderness river, the riverscape approach proved to be logistically feasible in the Elwha River. Surveys necessarily occurred during a short timeframe $(<1$ week $)$ to 

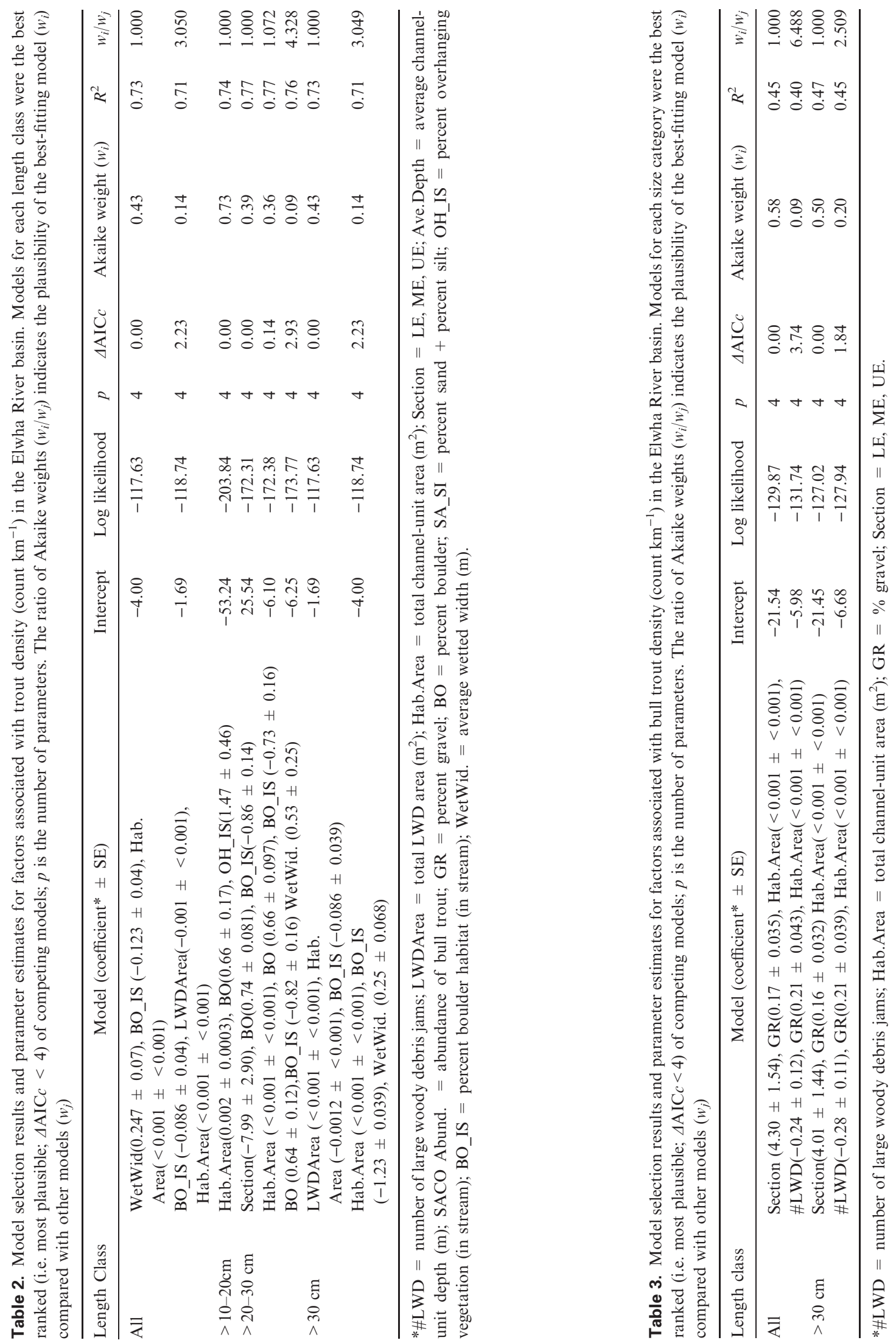
minimise the effects of fish movements within the river. Conversely, the narrow timeframe of the surveys provides only a snapshot of river fish assemblages during summer low flows and limits any evaluation of population trends over time. Such an evaluation would require more intensive and repeated sampling to account for the high inter-annual and temporal variability in fish abundances (Brenkman \& Connolly 2008; Dauwalter et al. 2009). Because sampling occurred only during summer low flows, key salmonid species such as adult coho and chum salmon and winter steelhead were missed, which typically enter the river in autumn. The snorkel methods were also ineffective at sampling benthic species (e.g. sculpins) and juvenile bull trout that are typically observed more at night (Thurow et al. 2006). Despite these limitations, the approach was relatively low in cost $(\$ 60000$ US per year) and provided multi-scale fish and habitat data in a remote wilderness river.

It was also not possible to survey the reservoirs $(8.5 \mathrm{~km})$ and portions of canyons with white water rapids $(\approx 8.8 \mathrm{~km})$. Rainbow trout and bull trout exist in each reservoir, and alternate sampling techniques, such as hydroacoustics, would be required to estimate their abundances. It is likely that some adfluvial bull trout moved upriver in the late summer and were detected during the snorkel surveys, particularly in the river above Lake Mills. The unsurveyed portions of white-water rapids in remote portions of canyons pose major challenges to any fish sampling technique. These canyons will serve as important migratory corridors and staging areas for salmonids that recolonise the upper portions of the watershed after dam removal.

\section{Conclusions}

The historic dam removal project in the Elwha River will provide an unprecedented opportunity for salmon recovery. One of the most important aspects of the project is the recolonisation of multiple salmonid species into pristine habitats protected within Olympic National Park. This study provides an important landscape-scale context for understanding the changes expected to occur in fish assemblage structure after dam removal, including: (1) upstream and downstream recolonisation by salmonids; (2) resumption of anadromy by upper river bull trout, rainbow trout and cutthroat trout populations; and (3) increased species richness in portions of the river upstream of the dams. A combination of the riverscape perspective and more traditional site-based, discontinuous fisheries surveys will likely be required to understand recolonisation at multiple temporal and spatial scales. In the light of the many upcoming dam removal projects in the western United States, increased monitoring efforts that focus on the collection of spatially continuous fish and habitat data should prove valuable for evaluating the effectiveness of dam removal at restoring anadromous salmonids and the riverscapes in which they reside.

\section{Acknowledgments}

Special thanks to M. Beirne, S. Corbett, P. Crain, J. Dunham, M. Elofson, J. Ganzhorn, C. Glenney, M. Groce, M. Hanks, B. Hoffman, H. Hugunin, P. Kennedy, D. Lantz, T. Leavy, S. Neil, S. Samson, D. Shreffler, I. Smith, J. Starr and L. Ward for field assistance. B. Baccus, L. Baysinger, C. Hawkins Hoffman, R. Hoffman and R. Reisenbichler provided logistical support. Funding was provided by Olympic National Park, U.S. Fish and Wildlife Service and U.S. Geological Survey. We thank T. Bennett, J. Ganzhorn, P. Roni and two anonymous reviewers for helpful comments on earlier drafts of this manuscript. Use of trade names is for convenience of the reader and does not constitute endorsement by the US government. The findings and conclusions in this article are those of the authors and do not necessarily represent the views of the U.S. Fish and Wildlife Service.

\section{References}

Abbe T.B. \& Montgomery D.R. (1996) Large woody debris jams, channel hydraulics and habitat formation in large rivers. Regulated Rivers: Research and Management 12, 201-221.

Allan J.D. (2004) Landscapes and riverscapes: the influence of land use on stream ecosystems. Annual Review of Ecology, Evolution, and Systematics 35, 257-284.

Bateman D.S., Gresswell R.E. \& Torgersen C.E. (2005) Evaluating single-pass catch as a tool for identifying spatial pattern in fish distribution. Journal of Freshwater Ecology 20, 335-345.

Baxter R.M. (1977) Environmental effects of dams and impoundments. Annual Review of Ecology and Systematics 8, 255-283.

Baxter C.V., Frissell C.A. \& Hauer F.R. (1999) Geomorphology, logging roads, and the distribution of bull trout spawning in a forested river basin: implications for management, and conservation. Transactions of the American Fisheries Society 128, 854-867.

Bednarek A.T. (2001) Undamming rivers: a review of the ecological impacts of dams and impoundments. Environmental Management 27, 803-814.

Beechie T.J., Liermann M., Beamer E.M. \& Henderson R. (2005) A classification of habitat types in a large river and 
their use by juvenile salmonids. Transactions of the American Fisheries Society 134, 717-729.

Benda L., Poff N.L., Miller D., Dunne T., Reeves G., Pess G. et al. (2004) Network dynamics hypothesis: spatial and temporal organization of physical heterogeneity in rivers. BioScience 54, 413-427.

Bisson P.A., Sullivan K. \& Nielsen J.L. (1988) Channel hydraulics, habitat use, and body form of juvenile coho salmon, steelhead, and cutthroat trout in streams. Transactions of the American Fisheries Society 117, 262273.

Bountry J., Ferrari R., Wille K. \& Randle T.J. (2010) 2010 survey report and area-capacity tables for Lake Mills and Lake Aldwell on the Elwha River, Washington. Denver, CO: U.S. Department of the Interior, Bureau of Reclamation, Technical Service Center Report No. SRH-201023, $66 \mathrm{p}$.

Brenkman S.J. \& Connolly P.J. (2008) Protocol for Monitoring Fish Assemblages in Pacific Northwest National Parks. Reston, VA: U.S. Geological Survey Techniques and Methods 2-A7, 128 pp. (available online at http:// pubs.usgs.gov/tm/tm2a7/).

Brenkman S.J., Pess G.R., Torgersen C., Kloehn K.K., Duda J.J. \& Corbett S.C. (2008a) Predicting recolonization patterns and interactions between potamodromous and anadromous salmonids in response to dam removal in the Elwha River, Washington State. Northwest Science 82(Special Issue), 91-106.

Brenkman S.J., Mumford S.L., House M. \& Patterson C. (2008b) Establishing a baseline for detection of fish pathogens in Pacific salmonids prior to dam removal and subsequent recolonization by anadromous fish in the Elwha River, Washington. Northwest Science 82(Special Issue), 142-152.

Burke B.J., Frick K.E., Moses R.E. \& McHenry M.L. (2008) Movements by Adult Coho Salmon in the Lower Elwha River, Washington. Northwest Science 82(Special Issue), 119-127.

Burnham K.P. \& Anderson D.R. (2002) Model Selection and Multimodel Inference: A Practical Information-Theoretic Approach, 2nd edn. New York, NY: Springer-Verlag, 488 pp.

Carbonneau P., Fonstad M.A., Marcus W.A. \& Dugdale S.J. (2011) Making riverscapes real. Geomorphology (in press).

Christie M.R., Marine M.L. \& Blouin M.S. (2011) Who are the missing parents? Grandparentage analysis identifies multiple sources of gene flow into a wild population. Molecular Ecology 20, 1263-1276.

Connolly P.J. \& Brenkman S.J. (2008) Fish assemblage, density, and growth in lateral habitats within natural and regulated sections of Washington's Elwha River. Northwest Science 82(Special Issue), 107-118.
Connor E.F., Courtney A.C. \& Yoder J.M. (2000) Individuals-area relationships: the relationship between animal population density and area. Ecology 81, 734-748.

Cummins K.W. (1962) An evaluation of some techniques for the collection and analysis of benthic samples with special emphasis on lotic waters. American Midland Naturalist 67, 477-504.

Curran C.A., Konrad C.P., Higgins J.H. \& Bryant M.K. (2009) Estimates of sediment load prior to dam removal in the Elwha River, Clallam County, Washington. U.S. Geological Survey Scientific Investigations Report 2009-5221, Tacoma, WA. 18 pp.

Dauwalter D.C., Rahel F.J. \& Gerow K.G. (2009) Temporal variation in trout populations: implications for monitoring and trend detection. Transactions of the American Fisheries Society, 138, 38-51.

Doyle M.W., Stanley E.H., Orr C.H., Selle A.R., Sethi S.A. \& Harbor J.M. (2005) Stream ecosystem response to small dam removal: lessons from the heartland. Geomorphology 71, 227-244.

Draut A.E., Logan J.B. \& Mastin M.C. (2010) Channel evolution on the dammed Elwha River, Washington, USA. Geomorphology 127, 71-87.

Duda J.J., Freilich J.E. \& Schreiner E.G. (2008) Baseline studies in the Elwha River ecosystem prior to dam removal: introduction to the special issue. Northwest Science 82(Special Issue), 1-12.

Duda J.J., Coe H.J., Morley S.A. \& Kloehn K.K. (In Press) Establishing spatial trends in water chemistry and stable isotopes $\left(\delta^{15} \mathrm{~N}\right.$ and $\left.\delta^{13} \mathrm{C}\right)$ in the Elwha River prior to dam removal and salmon recolonization. River Research and Applications doi: 10.1002/rra.1413.

Dunham J.B. \& Rieman B.E. (1999) Metapopulation structure of bull trout: influences of physical, biotic, and geometrical landscape characteristics. Ecological Applications 9, 642-655.

ESRI (2006) ArcGIS, Version 9.2. Redlands, CA: Environmental Systems Research Institute.

Fausch K.D. (1993) Experimental analysis of microhabitat selection by juveniles steelhead (Oncorhynchus mykiss) and coho salmon (O. kisutch) in a British Columbia stream. Canadian Journal of Fisheries and Aquatic Sciences 50, 1198-1207.

Fausch K.D., Torgersen C.E., Baxter C.V. \& Li H.W. (2002) Landscapes to riverscapes: bridging the gap between research and conservation of stream fishes. BioScience 52, 483-498.

Frissell C.A., Liss W.J., Warren C.E. \& Hurley M.D. (1986) A hierarchical framework for stream habitat classification: viewing streams in a watershed context. Environmental Management 10, 199-214.

Fullerton A.H., Burnett K.M., Steel E.A., Flitcroft R.L., Pess G.R., Feist B.E. et al. (2010) Hydrological connectivity 
for riverine fish: measurement challenges and research opportunities. Freshwater Biology 55, 2215-2237.

Gorman O.T. \& Karr J.R. (1978) Habitat structure and stream fish communities. Ecology 59, 507-515.

Gresswell R.E., Torgersen C.E., Bateman D.S., Guy T.J., Hendricks S.R. \& Wofford J.E.B. (2006) A spatially explicit approach for evaluating relationships among coastal cutthroat trout, habitat, and disturbance in small Oregon streams. In: R.M. Hughes, L. Wang \& P.W. Seelbach (eds). Landscape Influences on Stream Habitats and Biological Assemblages, Vol. 48. Bethesda, MD: American Fisheries Society, pp. 457-471.

Hankin D.G. \& Reeves G.H. (1988) Estimating total fish abundance and total habitat area in small streams based on visual estimation methods. Canadian Journal of Fisheries and Aquatic Sciences 45, 834-844.

Haring A.L. \& Fausch K.D. (2002) Minimum habitat requirements for establishing translocated cutthroat trout populations. Ecological Applications 12, 535-551.

Hart D.D., Johnson T.E., Bushaw-Newton K.L., Horwitz R.J., Bednarek A.T., Charles D.F. et al. (2002) Dam removal: challenges and opportunities for ecological research and river restoration. BioScience 52, 669-681.

Heinz Center (2002) Dam Removal: Science and Decision Making. Washington: The H. John Heinz III Center for Science, Economics, and the Environment, $221 \mathrm{pp}$.

Hyatt T.L. \& Naiman R.J. (2001) The residence time of large woody debris in the Queets River, Washington, USA. Ecological Applications 11, 191-202.

Kareiva P.M., Marvier M. \& McClure M. (2000) Recovery and management options for spring/summer Chinook salmon in the Columbia River basin. Science 290, 977-979.

Kiffney P.M., Greene C.M., Hall J.E. \& Davies J.R. (2006) Tributary streams create spatial discontinuities in habitat, biological productivity and diversity in main stem rivers. Canadian Journal of Fisheries and Aquatic Sciences 63, 2518-2530.

Kloehn K.K., Beechie T.J., Morley S.A., Coe H.J. \& Duda J.J. (2008) Influence of dams on river-floodplain dynamics in the Elwha River, Washington. Northwest Science 82(Special Issue), 224-235.

Labbe T.R. \& Fausch K.D. (2000) Dynamics of intermittent stream habitat regulate persistence of a threatened fish at multiple scales. Ecological Applications 10, 1774-1791.

Liermann M.C., Sharma R. \& Parken C. (2010) Using accessible watershed size to predict management parameters for Chinook salmon, Oncorhynchus tshawytscha, populations with little or no spawner-recruit data: a Bayesian hierarchical modeling approach. Fisheries Management and Ecology 17, 40-51.
Williams R.W., Laramie R.M. \& Ames J.J. (1975) A catalog of Washington streams and salmon utilization, Volume 1, Puget Sound Region. Olympia, WA: Washington Department of Fisheries, $2701 \mathrm{pp}$.

Lignon F.K., Dietrich W.E. \& Trush W.J. (1995) Downstream ecological effects of dams: a geomorphic perspective. BioScience 45, 183-192.

Morley S.A., Duda J.J., Coe H.J., Kloehn K.K. \& McHenry M.L. (2008) Benthic invertebrates and periphyton in the Elwha River basin: current conditions and predicted response to dam removal. Northwest Science $\mathbf{8 2}$ (Special Issue), 179-198.

National Hydrography Dataset (2009) U.S. Geological Survey. Available online at http://nhd.usgs.gov (accessed November 2009).

Northcote T.G. \& Wilkie D.W. (1963) Underwater census of stream fish populations. Transactions of the American Fisheries Society 92, 146-151.

Pess G.R. (2009) Patterns and Processes of Salmon Colonization. PhD. Thesis, Seattle: University of Washington, Seattle, 224 pp.

Pess G.R., McHenry M.L., Beechie T.J. \& Davies J. (2008) Biological impacts of the Elwha River dams and potential salmonid responses to dam removal. Northwest Science 82(Special Issue), 72-90.

Petts G.E. (1984) Impounded Rivers: Perspectives for Ecological Management. New York: John Wiley and Sons.

Petts G.E. \& Gurnell A.M. (2005) Dams and geomorphology: Research progress and future directions. Geomorphology 71, 27-47.

Pohl M.M. (2004) Channel bed mobility downstream from the Elwha dams, Washington. The Professional Geographer 56, 422-431.

R Development Core Team (2009) R: A Language and Environment for Statistical Computing. Vienna, Austria: R Foundation for Statistical Computing. Available online at http://www.R-project.org.

Radko M.A. (1997) Spatially Linking Basin-Wide Stream Inventories in a Geographic Information System. General Technical Report INT-GTR-345, Ogden, Utah: U.S. Department of Agriculture, Forest Service, Intermountain Research Station, 22 pp.

Raymond H.L. (1979) Effects of dams and impoundments on migrations of juvenile Chinook salmon and steelhead from the Snake River, 1966 to 1975. Transactions of the American Fisheries Society 108, 505-529.

Rice S., Kiffney P., Greene C. \& Pess G.R. (2008) The ecological importance of tributaries and confluences. In: S.P. Rice, A.G. Roy \& B.L. Rhoads (eds) River Confluences, Tributaries and the Fluvial Network. West Sussex, UK: John Wiley and Sons Ltd, pp. 209-242. 
Roni P. \& Quinn T.P. (1995) Geographic variation in size and age of North American Chinook salmon. North American Journal of Fisheries Management 15, 325-345.

Roni P., McHenry M., Pess G. \& Beechie T. (2008) Evaluating changes in salmon spawning habitat and spawners in the Elwha River following dam removal. American Fisheries Society Symposium 65, 301-319.

Roper B.B. \& Scarnecchia D.L. (1994) Summer distribution of and habitat use by Chinook salmon and steelhead within a major basin of the South Umpqua River, Oregon. Transactions of the American Fisheries Society 123, 298-308.

Rosenberg D.M., Berkes F., Bodaly R.A., Hecky R.E., Kelly C.A. \& Rudd J.W. (1997) Large-scale impacts of hydrological development. Environmental Reviews 5, 27-54.

Schill D.J. \& Griffith J.S. (1984) Use of underwater observations to estimate cutthroat trout abundance in the Yellowstone River. North American Journal of Fisheries Management 4, 479-487.

Shirvell C.S. (1990) Role of instream rootwads as juvenile coho salmon (Oncorhynchus kisutch) and steelhead trout (O. mykiss) cover habitat under varying streamflows. Canadian Journal of Fisheries and Aquatic Sciences 47, 852-861.

Stanley E.H. \& Doyle M.W. (2003) Trading off: the ecological effects of dam removal. Frontiers in Ecology and the Environment 11, 15-22.

Strahler A.N. (1957) Quantitative analysis of watershed geomorphology. Transactions of the American Geophysical Union 38, 913-920.

Thurow R.F. (1994) Underwater Methods for Study of Salmonids in the Intermountain West, General Technical Report INT-GTR-307, Ogden, Utah: U.S. Forest Service, Intermountain Research Station, 28 pp.

Thurow R.F., Peterson J.T. \& Guzevich J.W. (2006) Utility and validation of day and night snorkel counts for estimating bull trout abundance in first- to third-order streams. North American Journal 26, 217-232.
Torgersen C.E., Baxter C.V., Li H.W. \& McIntosh B.A. (2006) Landscape influences on longitudinal patterns of river fishes: spatially continuous analysis of fish-habitat relationships. In: R.M. Hughes, L. Wang \& P.W. Seelbach (eds) Landscape Influences on Stream Habitats and Biological Assemblages, Vol. 48. Bethesda, MD: American Fisheries Society, pp. 473-492.

Torgersen C.E., Gresswell R.E., Bateman D.S. \& Burnett K.M. (2008) Spatial identification of tributary impacts in river networks. In: S.P. Rice, A.G. Roy \& B.L. Rhoads (eds) River Confluences, Tributaries and the Fluvial Network. Chichester, UK: John Wiley \& Sons Ltd, pp. 159181.

Washington Department of Fisheries (1971) Elwha River Fisheries Studies. Crown Zellerbach Corporation Contract No. 0313. Olympia, WA: Washington Department of Fisheries Management and Research Division.

Watson G. \& Hillman T.W. (1997) Factors affecting the distribution and abundance of bull trout: an investigation at hierarchical scales. North American Journal of Fisheries Management 17, 237-252.

Wiens J.A. (2002) Riverine landscapes: taking landscape ecology into the water. Freshwater Biology 47, 501-515.

Williams J.G., Smith S.G., Muir W.D., Sandford B.P., Achord S., McNatt R. et al. (2005) Effects of the Federal Columbia River Power System on Salmon Populations. Seattle, WA: NOAA Technical Memorandum NMFSNWFSC-62, 150 pp.

Winans G.A., McHenry M., Baker J., Elz A., Goodbla A., Iwamoto E. et al. (2008) Genetic inventory of anadromous Pacific salmonids of the Elwha River prior to dam removal. Northwest Science 82(Special Issue), 128-141.

Winter B.D. \& Crain P. (2008) Making the case for ecosystem restoration by dam removal in the Elwha River, Washington. Northwest Science 82(Special Issue), 13-28.

Wunderlich R.C., Winter B.D. \& Meyer J.H. (1994) Restoration of the Elwha River ecosystem. Fisheries 19, 11-19. 